\title{
Seasonal and interannual coastal wind variability off the central Maluku Islands revealed by satellite oceanography
}

\author{
Setiawan R.Y. ${ }^{1}$, Iskandar I. ${ }^{2 *}$, Wirasatriya A. ${ }^{3,4}$, Dwi Susanto R. ${ }^{5}$, Siswanto E. ${ }^{6}$, Pranowo W.S. ${ }^{7,8}$, Setiawati M.D. ${ }^{9}$ and \\ Mardiansyah W. ${ }^{2}$ \\ ${ }^{1}$ Department of Fisheries, Faculty of Agriculture, Universitas Gadjah Mada, Yogyakarta, Indonesia \\ ${ }^{2}$ Department of Physics, Faculty of Mathematics and Natural Sciences, University of Sriwijaya, Indralaya, OI, South Sumatera, Indonesia \\ ${ }^{3}$ Department of Oceanography, Faculty of Fisheries and Marine Science, Diponegoro University, Semarang, Indonesia \\ ${ }^{4}$ Center for Coastal Rehabilitation and Disaster Mitigation Studies, Diponegoro University, Semarang, Indonesia \\ ${ }^{5}$ Department of Atmospheric and Oceanic Science, University of Maryland, College Park, MD, USA \\ ${ }^{6}$ Earth Surface System Research Center (ESS), Research Institute for Global Change (RIGC), Japan Agency for Marine-Earth Science and \\ Technology (JAMSTEC), Yokohama, Japan \\ ${ }^{7}$ Marine Research Center, Ministry of Marine Affairs and Fisheries of the Republic of Indonesia, Jakarta, Indonesia \\ ${ }^{8}$ Department of Hydrography, Indonesia Naval Postgraduate School (STTAL), Jakarta, Indonesia \\ ${ }^{9}$ Research Center for Oceanography, National Research and Innovation Agency (BRIN), Jakarta, Indonesia \\ Received: 15/11/2021, Accepted: 04/01/2022, Available online: 05/01/2022 \\ *to whom all correspondence should be addressed: e-mail: iskhaq@mipa.unsri.ac.id \\ https://doi.org/10.30955/gnj.004177
}

\section{Graphical abstract}
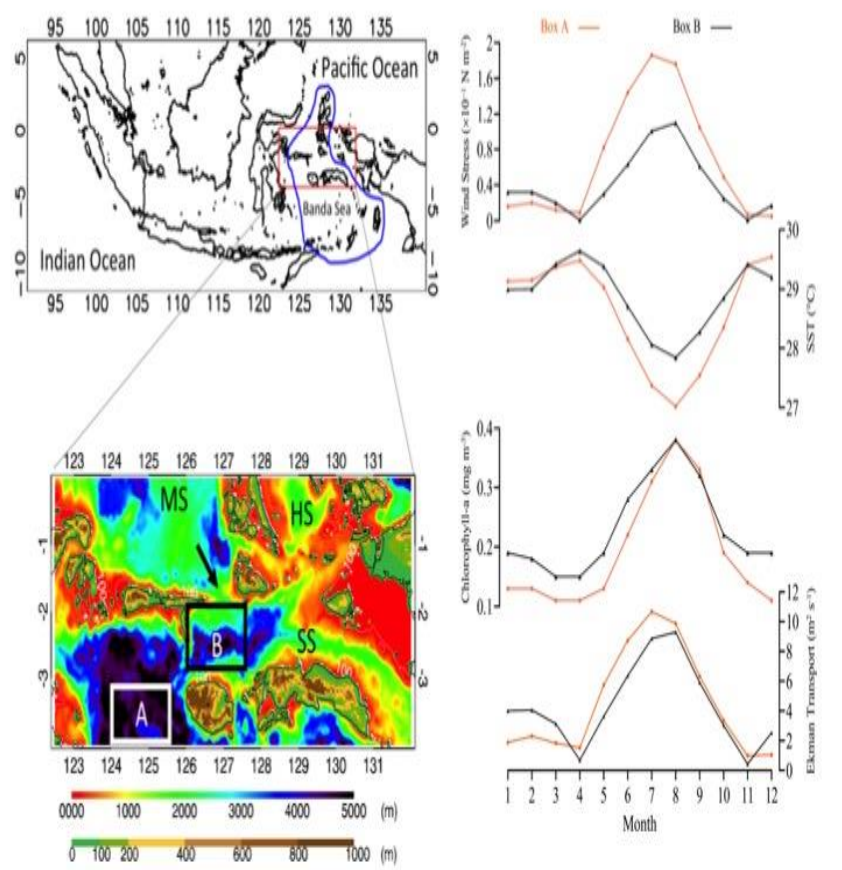

Figure. (Upper-left panel) Maps of the Maluku Islands (blue line), and (lower-left panel) of topography and bathymetry (m) of the central Maluku Isands (red box). MS, HS, and SS denote the Maluku, Halmahera, and Seram Seas. (Right panel) time series of wind stress, SST, chlorophyll-a, and Ekman transport over regions of 1249E-125.59E, 395-495 (BoX A) and 1269E-127.59E, 195-2.595 (Box B).

\section{Abstract}

The Maluku Islands (henceforth $\mathrm{MI}$ ) are situated in the northeastern Indonesia. Ocean region off the central MI is pivotal as it provides a course for the Indonesian Throughflow (ITF) through the Lifamatola passage. However, sea surface dynamics off the central $\mathrm{Ml}$ is unknown until recently due to inadequate measurements. The current fact motivates the present study to decipher the coastal wind variability off the central MI and its effect on the sea surface by analysing long-term datasets (20072019) of satellite-derived sea surface wind, sea surface temperature (SST), and surface chlorophyll-a concentration. Possible influence of extreme climate events of the 2015 El Niño-Southern Oscillation (ENSO) and the 2019 Indian Ocean Dipole (IOD) on all oceanographic parameters was also examined. Results show that the prevailing southeasterly winds over the central MI induce SST cooling and phytoplankton bloom. Correlation analysis revealed that the ENSO and IOD play significant roles in defining spatial distribution of the coastal wind, SST, and phytoplankton bloom in the research area. In addition, the anomaly analysis exhibits distinct oceanographic features during the climate extreme events of 2015 and 2019. Collectively, results of the present research highlight the importance of coastal wind variability and extreme events in shaping the ocean surface characteristics and perhaps regional fisheries production.

Keywords: ENSO, IOD, Maluku Islands, sea surface temperature, winds

\section{Introduction}

Sea surface winds play a pivotal role in regulating ocean surface dynamics in the Indonesian Seas. Typically, the northwesterly (southeasterly) winds exert downwelling 
(upwelling) in many coastal areas in the Indonesian Seas, as indicated by high (low) sea surface temperature (SST) (Kurniawati et al, 2021; Muskananfola et al., 2021; Setiawan et al., 2019;2020; Siswanto et al, 2020; Wirasatriya et al., 2020a; 2021). Wind variability in the region is principally affected by the Australian Indonesian Monsoon (AIM) system, which generates the prevailing of northwesterly winds from December to February (Austral summer) and the southeasterly winds from June to September (Austral winter) (Gordon, 2005). The northwesterly winds carry moist air and cause heavy rainfall over the Indonesian Maritime Continent, while the southeasterly winds transport dry air and induce dry season over the region (Gordon, 2005). Sea surface condition of the Indonesian Seas is also modulated by the El Niño-Southern Oscillation (ENSO) and the Indian Ocean Dipole (IOD), i.e. the sea surface experiences fierce wind forcing during the EI Niño/positive IOD year and weak wind forcing during the La Niña/negative IOD year (Iskandar et al., 2017; Kurniawati et al., 2021; Setiawan et al., 2019; Siswanto et al., 2020; Susanto and Marra, 2005; Susanto et al., 2006; Wirasatriya et al., 2020b). These two climate modes may have exerted an essential role in controlling health of the marine environment and fish resource distribution in the Indonesian Seas. Hence, examining the variability of the AIM winds and their effect on the sea surface is essential for marine and coastal resource management of the Indonesian fisheries management areas.

The $\mathrm{MI}$ is situated in the northeastern Indonesia and comprises many small islands. Of particular interest here is the ocean region off the central MI provides a fishing hotspot for commercial fishes (Hutubessy et al., 2014) as well as a pathway for the ITF via the Lifamatola passage (black arrow in Figure 1 right panel) (e.g., Sprintall et al., 2014). The central MI waters are characterized by complex bathymetry and connected to the Maluku and Halmahera Seas in the north and the Banda Sea in the south. Furthermore, the region of interest is located in the Coral Triangle, one of the most diverse places due to its high species richness of coral, demersal fish, and sea turtle (DeVantier et al., 2004; Veron et al., 2006). This biodiverse region has delivered services through seafood resources and tourism for the people and the nation. Unfortunately, physical forcing like monsoon wind that controls sea surface conditions off the central $\mathrm{Ml}$ is unknown due to lack of long-term in situ measurements. Variation of this wind may have played a substantial role in sustaining life of the marine realm in the ocean region off the central MI.

In addition to seasonal forcing, the $\mathrm{MI}$ also experiences interannual modulation by the Indo-Pacific climate modes, namely ENSO and IOD. The ENSO is an interannual climate anomaly in the tropical Pacific Ocean (e.g., McPhaden et al., 2006). The El Niño event of 2015 has been suggested as one of the robust El Niño events in the record (Hu and Fedorov, 2017; Palmeiro et al., 2017). It was characterized by considerable positive SST anomalies that dominated the tropical Pacific Ocean (L'Heureux et al., 2017). Levine and McPhaden (2016) suggested the multiple westerly wind bursts were liable for the advection of water mass from the Western Pacific Warm Pool into the central Pacific, which in turn enhanced the development of a strong El Niño like in 2015.

Meanwhile, the IOD is a climate mode associated with zonal SST gradient (east-west) in the tropical Indian Ocean (Saji et al., 1999). Positive IOD event that occurred during boreal fall 2019 was categorized as an extreme event (Doi et al., 2020; Ratna et al., 2021). The 2019 positive IOD event's primary forcing was thought to be the existence of enhanced sea level pressure over Australia and declined sea level pressure over the South China Sea since May 2019 (Lu and Ren, 2020). This inter-hemispheric gradient of sea level pressure invoked the northward cross-equator over the Indonesian Seas and accelerated wind speed over the southeastern tropical Indian Ocean, leading to the evolution of positive IOD events via Kelvin waves forcing (Delman et al., 2016; Lu and Ren, 2020). We hypothesize the two extreme climate events of 2015 and 2019 have profound effects on the Indonesian Seas' oceanic condition. Given the importance of the ocean region off the central $\mathrm{MI}$, disentangling coastal wind variability and the detailed effect of both extreme events on the sea surface will contribute to the successful prediction of future climate extreme events in the region.

The development of robust remote sensing technology has enabled us to investigate long-term surface ocean dynamics. Earlier investigations have shown the capability of the Moderate Resolution Imaging Spectroradiometer (MODIS) data in revealing long-term variability of chlorophyll-a and SST regionally and globally (e.g., Mao et al., 2017; Muhammad et al., 2016; Setiawan et al., 2019). In the present work, we analyse 12 years (2007-2019) of satellite-derived sea surface wind, SST, and surface chlorophyll-a to decipher seasonal and interannual variations of the sea surface condition off the central MI. Moreover, we elucidate the effect of the $2015 \mathrm{El}$ Niño and the 2019 positive IOD events on the ocean parameters. Results of this research can be used to manage better marine and fisheries resources in the central MI region.

\section{Materials and methods}

\subsection{Materials}

We employed KNMI Global Wind Level-3 data of spatial resolution of $0.125^{\circ} \times 0.125^{\circ}$ of the Advanced Scatterometer (ASCAT) to unveil surface wind variation off the central MI. The analysis period of this study goes from January 2007 to December 2019. The ASCAT onboard the Meteorological Operational (MetOp) satellite can acquire wind data (speed and direction) in the coastal area and open ocean with an accuracy of $\sim 2 \mathrm{~m} \mathrm{~s}^{-1}$ (Verhoef and Stoffelen, 2013). The ASCAT wind data is available at the Copernicus Marine Environment Monitoring Service (https://resources.marine.copernicus.eu/product-detail/ WIND_GLO_WIND_L3_REP_OBSERVATIONS_012_005/SER VICES).

In order to decipher the effect of wind on the ocean surface off the central MI, the Level-3 data of $11-\mu \mathrm{m}$ SST and chlorophyll-a retrieved from the Moderate Resolution 
Imaging Spectroradiometer (MODIS) onboard the Aqua satellite were examined. The spatial resolution of the MODIS SST and chlorophyll-a data is $0.04^{\circ} \times 0.04^{\circ}$ (Esaias et al, 1998), and both data have been documented to accurately record SST and chlorophyll-a concentration (e.g., Ghanea et al., 2016). The MODIS SST and chlorophyll-a data were downloaded from the Physical Oceanography Distributed Active Archive Center of NASA (https://podaac-tools.jpl.nasa.gov/drive/files/allData/mod is/L3/aqua) and were analysed for the period of January 2007 to December 2019.

The Oceanic Niño Index (ONI) and the Dipole Mode Index (DMI) were used to determine ENSO events (EI Niño and La Niña) and IOD events, respectively. Specifically, we used the Niño3.4 SST anomaly index. The ONI data is generated by the National Ocean and Atmospheric Administration Climate Prediction Center and is accessible at https://www.cpc.ncep.noaa.gov/data/indices/oni.ascii. txt. The DMI data is generated by the Japanese Agency for Marine-Earth Science Technology (JAMSTEC) and is attainable at https://stateoftheocean.osmc.noaa.gov/sur/ ind/dmi.php.

\subsection{Methods}

The wind stress $(\tau)$ on the ocean surface and the Ekman Mass Transport (EMT) were calculated by employing the equation of Hsieh and Boer (1992),

$$
\begin{aligned}
& \tau=\rho_{a} C_{d} U_{10}^{2} \\
& E M T_{x}=\frac{\left(\delta \tau_{x}+f \tau_{y}\right)}{\rho_{w}\left(f^{2}+\delta^{2}\right)} \\
& E M T_{y}=\frac{\left(\delta \tau_{y}-f \tau_{x}\right)}{\rho_{w}\left(f^{2}+\delta^{2}\right)}
\end{aligned}
$$

where $\rho_{\alpha}$ is the density of air $\left(1.25 \mathrm{~kg} \mathrm{~m}^{-3}\right), \rho_{w}$ is the density of seawater $\left(1.025 \times 10^{3} \mathrm{~kg} \mathrm{~m}^{-3}\right), C_{D}$ is the drag coefficient, $U_{10}$ is the wind speed of $10 \mathrm{~m}$ above sea level, $\delta$ is frictional dumping parameter $\left(480^{-1}\right.$ days $)$, and $f$ is the Coriolis parameter. EMT $T_{x}$ and $E M T_{y}$ express zonal and meridional direction of the EMT, respectively.

All satellite data were averaged into monthly means. The data were then computed into monthly climatological mean by following the equation of Wirasatriya et al. (2017),

$$
\bar{X}(x, y)=\frac{1}{n} \sum_{i=1}^{n} x i(x, y, t)
$$

where $\bar{X}(x, y)$ is monthly average or monthly climatology value at location $(x, y), x i(x, y, t)$ is the $i$-th value of the data at $(x, y)$ and time $t, n$ is the number of data in a one-month period and the number of monthly data in one period of climatology (2007-2019). Note that hollow pixels were excluded in the calculation.

The monthly climatology time series for all oceanographic parameters were constructed by averaging all oceanographic parameters over the region of 124 으125.5으, 3S-4오 (Box A), and 126ㅌ-127.5으, 1으-2.5으
(Box B) to understand better the variations of ocean wind, SST, and surface chlorophyll-a in the region off the central MI. This time series is displayed in Figure $1 \mathrm{~b}$.
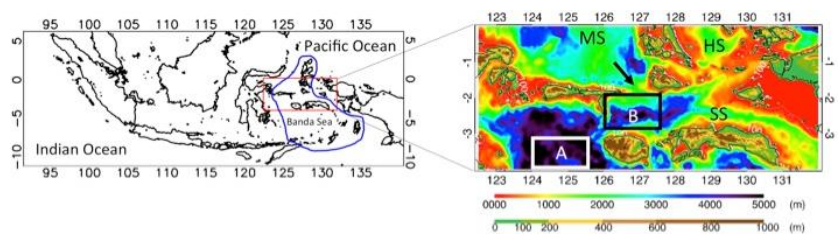

Figure 1. Maps of the Maluku Islands (blue line), and of topography and bathymetry $(\mathrm{m})$ of the central Maluku Islands (red box). MS, HS, and SS denote the Maluku, Halmahera, and Seram Seas.

To examine the effects of the 2015 El Niño and the 2019 positive IOD, we performed monthly anomaly analysis to all oceanographic parameters. Furthermore, correlation analysis between oceanographic parameters and the ONI and DMI was computed to highlight the effect of extreme climate events on the ocean region off the central MI.
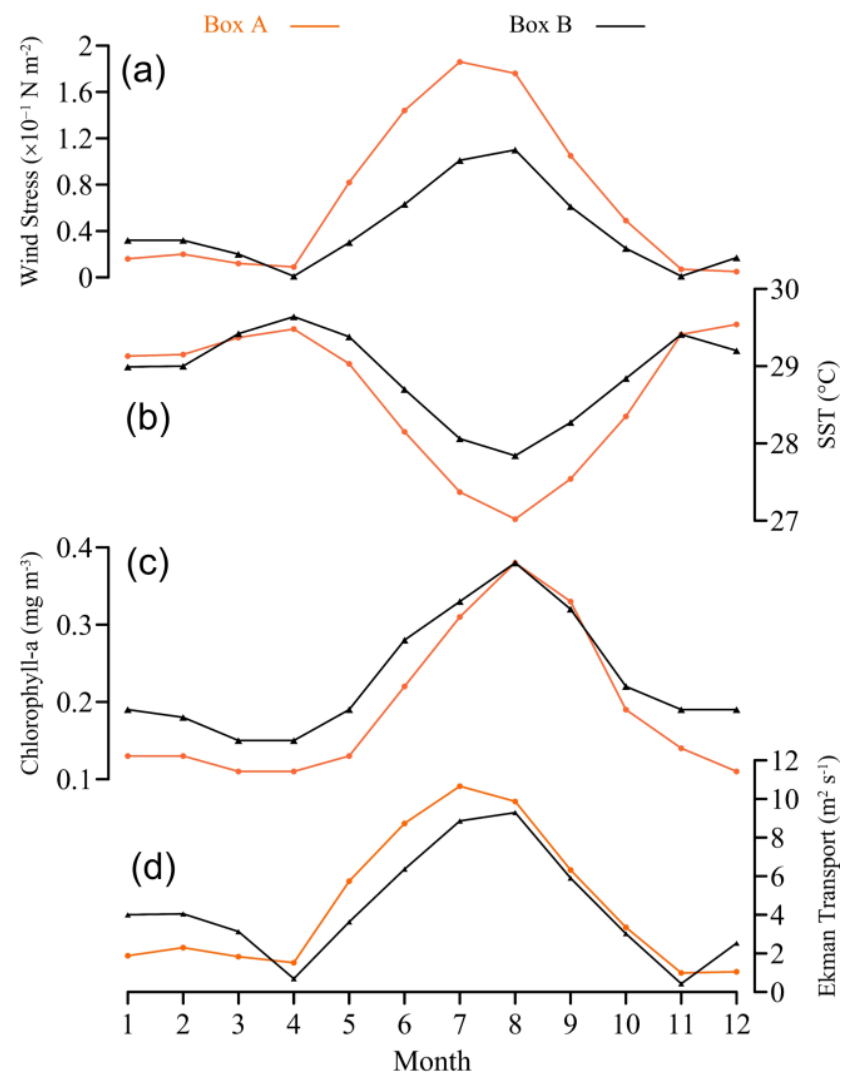

Figure 2. Time series of (a) wind stress, (b) SST, (c) chlorophyll-a, and (d) Ekman transport over regions of 124ㅌ-125.5트, 3으-4오 (Box A) and 126으-127.5으, 1ㅇ-S-2.5으 (Box B).

\section{Results}

Analyses of monthly climatology of sea surface wind stress over the central MI from December to February, and from June to September are demonstrated in Figure 2a, 3a, and 4a. It is seen that the northeasterly winds prevail over the investigated area from December to February with a magnitude of less than $0.4 \times 10^{-1} \mathrm{~N} \mathrm{~m}^{-2}$. Meanwhile, the 
southeasterly wind stresses prevail from June to September with a magnitude of more than $0.4 \times 10^{-1} \mathrm{~N} \mathrm{~m}^{-2}$. Our results show the strongest wind occurred in July and August (Figure 2a).

(a)

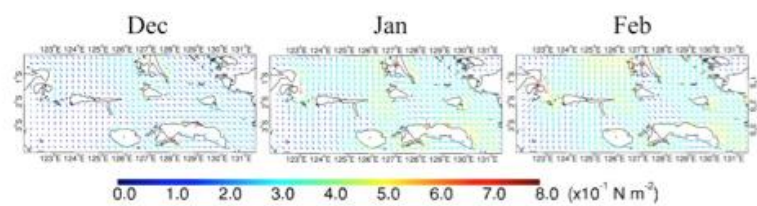

(b)

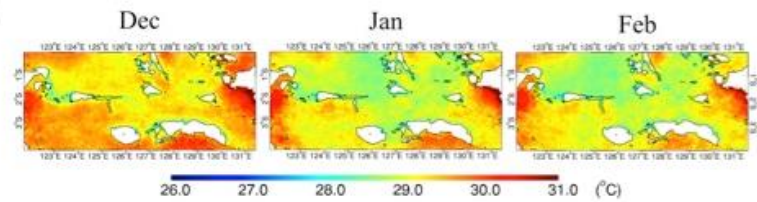

(c)

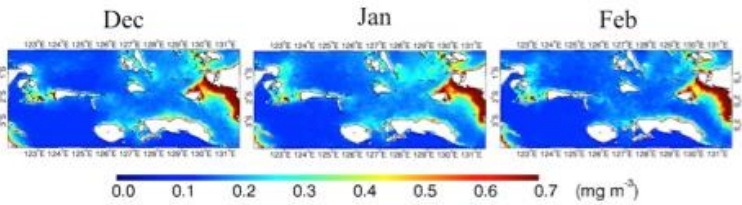

(d)

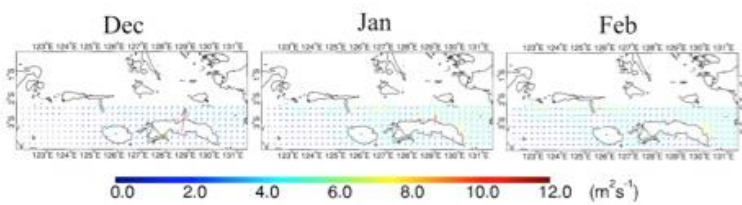

Figure 3. Monthly climatology maps of (a) surface wind stress, (b) SST, (c) surface chlorophyll-a, and (d) EMT during the Austral summer.

(a)

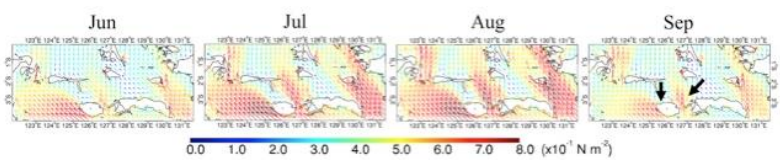

(b)

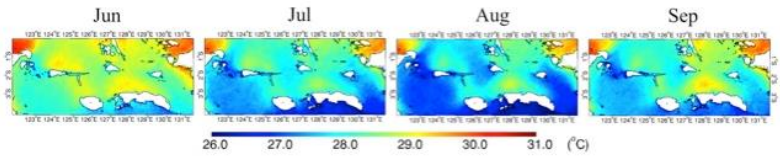

(c)
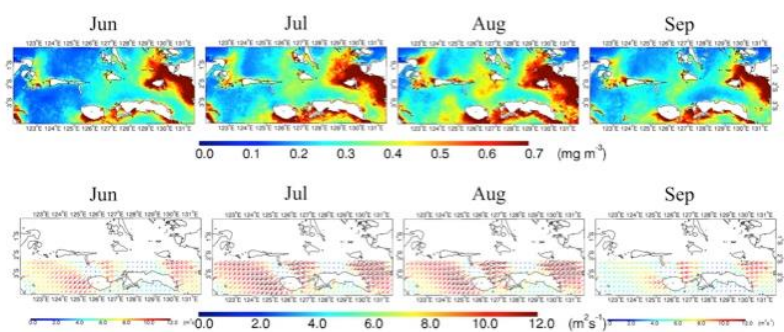

Figure 4. Monthly climatology maps of (a) surface wind stress, (b) SST, (c) surface chlorophyll-a, and (d) EMT during the Austral winter.

SST off the central MI shows relatively higher SST (> 29ㅇ) from December to February compared to that during the period of June-September (Figure 2b, 3b, and 4b). Indeed, the evolution of SST cooling is prominent during the latter time, with the coldest SST $\left(<28^{\circ} \mathrm{C}\right)$ takes place in August (Figure 2b).

Figure 2c, 3c, and 4c exhibit monthly climatology of surface chlorophyll-a concentration off the central $\mathrm{MI}$ during the Austral summer and Austral winter. There is a phytoplankton bloom occurrence off the central $\mathrm{Ml}$ that evolved during the Austral winter. We found a chlorophyll-a maximum of $0.38 \mathrm{mg} \mathrm{m}^{-3}$ in August, in contrast, a low phytoplankton biomass occupies the studied area during the Austral summer as indicated by chlorophyll-a concentration less than $0.2 \mathrm{mg} \mathrm{m}^{-3}$ (Figure 2c).

In line with the wind stress, strong EMT $\left(>5 \mathrm{~m}^{2} \mathrm{~s}^{-1}\right)$ observed in the ocean region off the central $\mathrm{MI}$ from June to September (Figure 2d, 3d, and 4d). On the other hand, a relatively weak EMT $\left(<4 \mathrm{~m}^{2} \mathrm{~s}^{-1}\right)$ persisted from December to February. The predominant direction of EMT during June-September (December to February) period is southwestward (northeastward).

\section{Discussion}

The present research demonstrates that the coastal wind variability off the central $\mathrm{MI}$ is dynamically affected by the AIM winds. Climatological maps of surface wind from June to September show intense southeasterly wind stresses (> $0.6 \times 10^{-1} \mathrm{~N} \mathrm{~m}^{-2}$ ) persisted in the area of interest. Simultaneously, there is an elevation in surface chlorophyll-a concentration, while the SST significantly decreases. We postulate coastal upwelling occurred in the region results in a phytoplankton bloom event (Figure 2c, $4 b$, and $4 c$ ). An upwelled of nutrient-rich water from the deeper depth to the surface may invoke phytoplankton bloom events off the central MI from June to September. Our inference is corroborated by the EMT values that denote higher values (> $5.5 \mathrm{~m}^{2} \mathrm{~s}^{-1}$ ) during the period compared to December-February (Figure 2d, 3d, and 4d). Moreover, our results reveal the interaction between surface winds and central $\mathrm{Ml}$ topography is apparent here, i.e. the existence of coastal mountains and small straits (indicated by black arrows in Figure 4a) shaped wind regime in the research site. The location and direction of enhanced wind stress and EMT are well fit with the position of significant SST cooling and phytoplankton bloom (Figure 4). Indeed, coastal mountains in the region cause celerity of the southeasterly wind stress via orography mechanism. This observation may imply that the surface ocean productivity and fish resource distribution in the region are likely determined by the variability of the coastal wind jet. We notice that orographic alteration of surface wind is commonplace in seas off the central $\mathrm{Ml}$ and possibly in other regional seas within the Indonesian archipelago.

The northeasterly wind stresses seem unable to force coastal upwelling off the central MI from December to February. Hence, a phytoplankton bloom event in the investigated area is absent. It is evident here that the phytoplankton bloom diminished when the coastal wind stresses weakened $\left(<0.4 \times 10^{-1} \mathrm{~N} \mathrm{~m}^{-2}\right)$ (Figure $2 \mathrm{c}$ and $4 \mathrm{a}-\mathrm{c}$ ). The deceleration of wind forcing in this area also causes SST to increase $\left(>28^{\circ} \mathrm{C}\right)$. Besides the faint wind, we propose solar insolation maxima may promote high SST in the site. Furthermore, there is a high chlorophyll-a spot observed in the southeastern Halmahera Sea. According to Setiawan et al. (2020), the chlorophyll-a maxima there are induced by continental runoff, not coastal upwelling. 
The present research also examines the ENSO and IOD's effect on the coastal wind variation off the central MI. We focus on the period of June-September due to the robustness of coastal wind stresses during this time. We found a remarkable positive correlation between the ENSO and coastal wind stresses from June to September (Figure 5a). The correlation between the ENSO and EMT yields a similar result (Figure $5 \mathrm{~d}$ ), demonstrating the ENSO strongly modulates the occurrence of phytoplankton bloom off the central $\mathrm{Ml}$ through Ekman upwelling. This premise is corroborated by a pronounced negative correlation between the ENSO and SST from June to September (Figure 5b-c). Good correlations among oceanographic parameters here suggest the dominant influence of ENSO in governing surface ocean productivity off the central MI during the Austral winter.

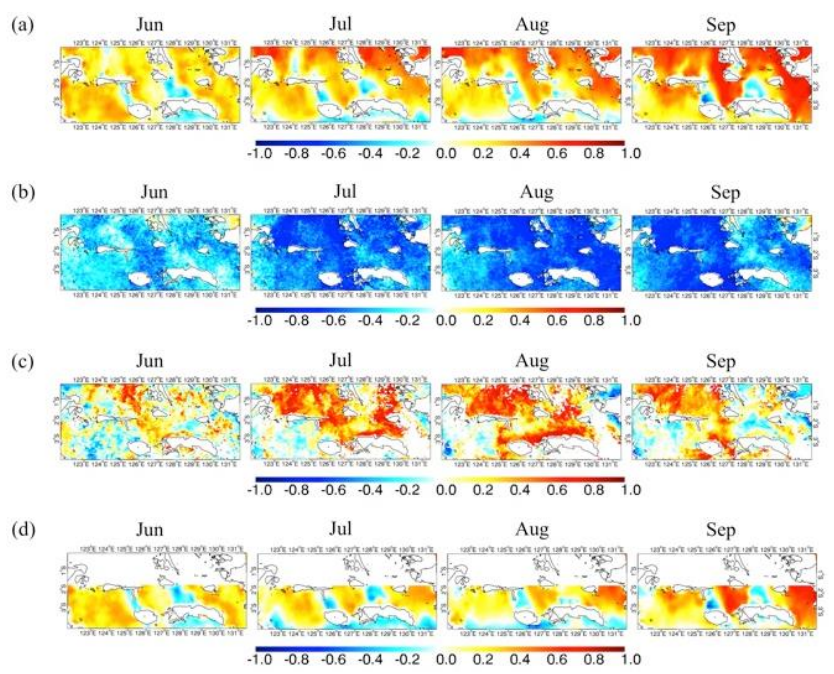

Figure 5. Correlation between $\mathrm{ONI}$ and monthly (a) surface wind stress, (b) SST, (c) surface chlorophyll-a, (d) EMT during the Austral winter.

(a)

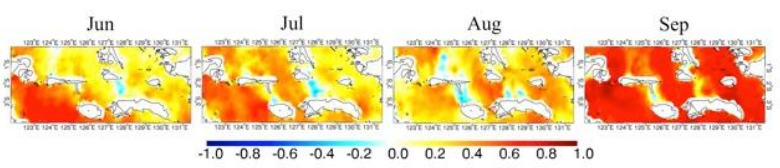

(b)

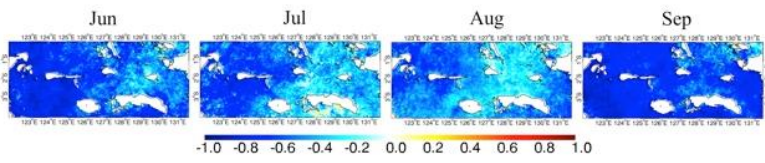

(c)

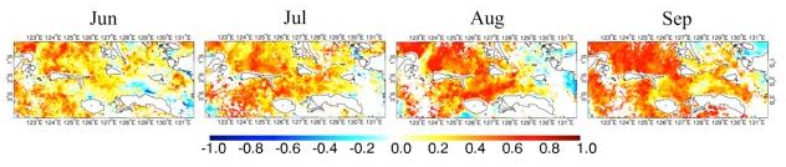

(d)

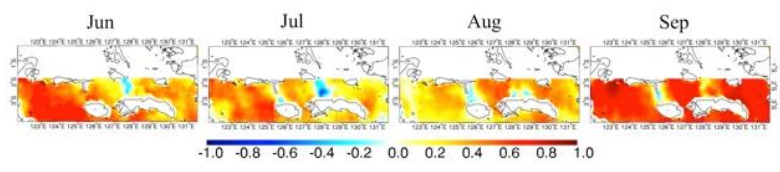

Figure 6. Correlation between DMI and monthly (a) surface wind stress, (b) SST, (c) surface chlorophyll-a, (d) EMT during the Austral winter.

The correlation between IOD and oceanographic parameters from June to September is depicted in Figure
6. Note that the IOD event indicates seasonal phase-lock: develops in boreal late spring/early summer, peaks in late summer/fall, and terminates in early winter. For this reason we performed the correlation analysis during the period of July - September when the IOD reached its peak. Likewise, the effect of IOD on the coastal wind, SST, phytoplankton biomass off the central $\mathrm{MI}$ is vigorous. Positive correlations between the IOD and surface wind stresses, phytoplankton bloom, and EMT (Figure 6) are noticeable during the Austral winter. Seemingly, coastal wind stresses are favourable for generating phytoplankton bloom and SST cooling when the IOD operates.

(a)

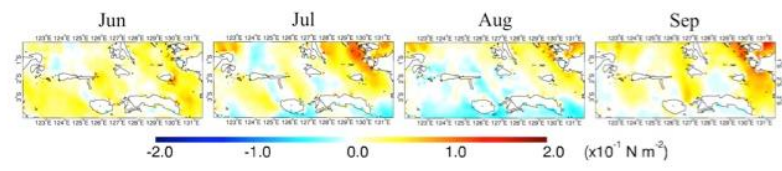

(b)

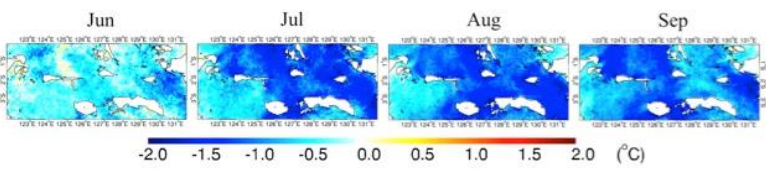

(c)
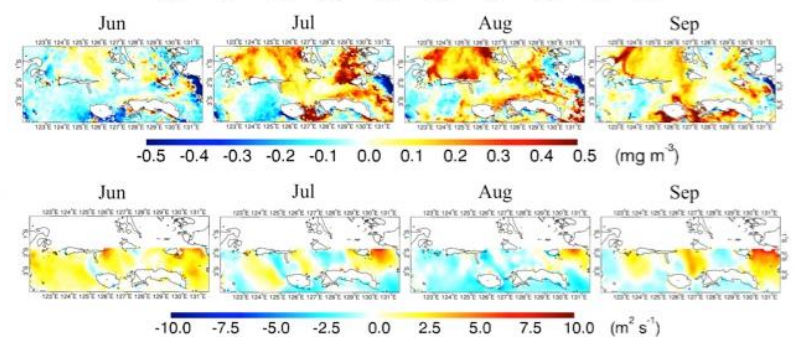

Figure 7. Anomaly maps of (a) surface wind stress, (b) SST, (c) surface chlorophyll-a, and (d) EMT during the Austral winter of 2015.

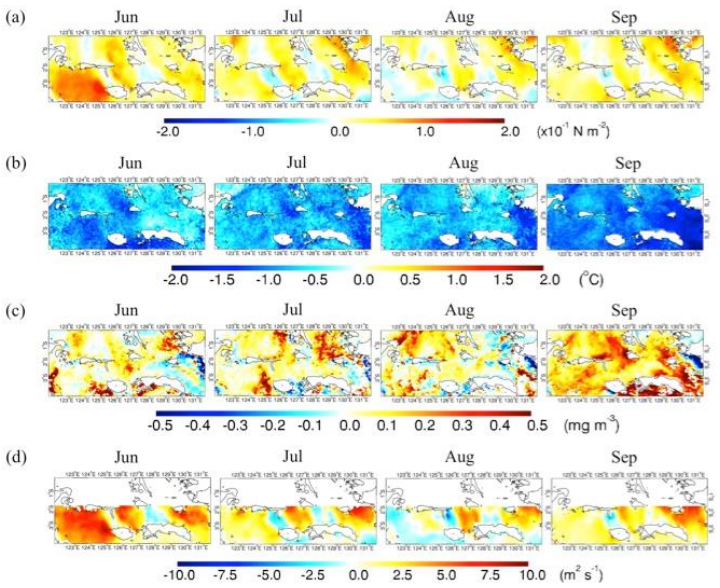

Figure 8. Anomaly maps of (a) surface wind stress, (b) SST, (c) surface chlorophyll-a, and (d) EMT during the Austral winter of 2019.

Moreover, the present research has evaluated the consequence of extreme climate events, particularly the 2015 El Niño and the 2019 positive IOD, on the coastal wind intensity from June to September. When an extreme El Niño event took place in 2015, positive anomalies are conspicuous in the surface wind stresses (Figure 7a), surface chlorophyll-a concentration (Figure 7c), and EMT (Figure 7d). This finding suggests that wind stresses' 
strength and direction may have determined the spatial distribution of sea surface productivity off the central MI during this time frame, implying such anomaly may evoke a consequence on the regional seafood stock via a decline or increase in fisheries production.

During the 2019 positive IOD event (June-September), sea surface off the central MI showed significant positive anomalies in surface wind stress, surface chlorophyll-a concentration, EMT, and a negative anomaly in SST (Figure 8). The centre of positive chlorophyll-a anomaly is located congruently with the positions of wind stress, SST, and EMT anomalies (Figure 8). Indeed, the orography effect is visible during this event, i.e. the positive chlorophyll-a anomaly was generated by energetic wind stresses via mixed layer disturbances, leading to phytoplankton bloom and cold SST. Collectively, we conclude that the effects of the 2015 and 2019 extreme events on the sea surface off the central MI are robust. Furthermore, our results emphasized the significance of large-scale climate events in governing surface dynamics of the regional sea.

\section{Conclusion}

Our research has demonstrated that satellite-derived sea surface wind stress, SST, and surface chlorophyll-a concentration are applicable in revealing sea surface dynamics off the central MI. We discovered that southeasterly winds play a critical role in modifying sea surface condition of the study area, i.e. by lowering SST and generating phytoplankton bloom. The SST cooling and phytoplankton bloom occur in response to enhanced surface wind stress and EMT. On the other hand, the SST cooling and phytoplankton bloom deteriorated when wind stress and EMT weakened. The correlation analysis revealed that the ENSO and IOD affect all oceanographic parameters as denoted by positive correlations in wind stress, EMT, chlorophyll-a, and negative correlation in SST. In accordance with the correlation analysis, anomaly analysis suggests positive anomalies in wind stress, EMT, chlorophyll-a concentration, and negative anomaly in SST during the extreme events of 2015 and 2019. Overall, results of this research highlight the importance of coastal wind and extreme climate events in shaping ocean conditions and perhaps regional fisheries production.

\section{Funding}

This work was supported by the Ministry of Education, Culture, Research and Technology, Republic of Indonesia through Penelitian Dasar Unggulan Perguruan Tinggi (PDUPT) Number: 150/E4.1/AK.04.PT/2021.

\section{Declaration of Competing Interest}

The authors declare that there is no conflict of interest regarding the publication of this paper.

\section{Acknowledgement}

II is supported by the Ministry of Education, Culture, Research and Technology, Republic of Indonesia through Penelitian Dasar Unggulan Perguruan Tinggi (PDUPT) Number: 150/E4.1/AK.04.PT/2021. RYS also acknowledges the Ministry of
Education, Culture, Research and Technology, Republic of Indonesia and the University of Gadjah Mada for the research grants (6/E1/KP.PTNBH/2021 and 2193/UN1/DITLIT/DITLIT/PT/2021). AW thanks to the University of Diponegoro for the research grant (185-98/UN7.6.1/PP/2021). The authors thank the E.U. Copernicus Marine Service Information and the Physical Oceanography Distributed Active Archive Center. The authors thank to Venny Sri and Wahdiny Nasution for the massive supports. The authors also wish to thank the anonymous reviewers for their careful reading of the manuscript and constructive suggestions for improvement.

\section{References}

Delman A.S., Sprintall J.J., McClean L. and Talley L.D. (2016). Anomalous java cooling at the initiation of positive indian ocean dipole events. Journal of Geophysical Research: Oceans, 121, 5805-5824. https://doi.org/10.1002/2016JC011635.

DeVantier L., Alcala A. and Wilkinson C. (2004). The SuluSulawesi Sea: environmental and socioeconomic status, future prognosis and ameliorative policy options. Ambio, 33(1-2), 88-97. https://doi.org/10.1579/0044-7447-33.1.88.

Esaias W.E., Abbott M.R., Barton I., Brown O.B., Campbell J.W., Carder K.L., Clark D.K., et al. (1998). An overview of MODIS capabilities for ocean science observations. IEEE Transactions on Geoscience and Remote Sensing, 36(4), 1250-1265. https://doi.org/10.1109/36.701076.

Ghanea M., Moradi M., Kabiri K. and Mehdinia, A. (2016). Investigation and validation of MODIS SST in the Northern Persian Gulf. Advances in Space Research, 57(1), 127-136. https://doi.org/10.1016/j.asr.2015.10.040.

Gordon A.L. (2005). Oceanography of the Indonesian Seas and Their Throughflow. Oceanography, 18(4), 14-27. https://doi.org/10.5670/oceanog.2005.01.

Group T.W. (1988). The WAM model-A third generation ocean wave prediction model. Journal of Physical Oceanography, 18, 1775-1810. https://doi.org/10.1175/15200485(1988)018\%3C1775:TWMTGO\%3E2.0.CO;2.

Hsieh W.W. and Boer G.J. (1992). Global climate change and ocean upwelling. Fisheries Oceanography, 1(4), 333-338. https://doi.org/10.1111/j.1365-2419.1992.tb00005.x.

Hu S. and Fedorov A.V. (2017). The extreme El Niño of 20152016 and the end of global warming hiatus, Geophysical Research Letters, 44, 3816-3824. https://doi.org/10. 1002/2017GL072908.

Iskandar I., Sari Q.W., Setiabudiday D., Yustian I. and Monger B. (2017). The distribution and variability of chlorophyll-a bloom in the southeastern tropical Indian Ocean using empirical orthogonal function analysis. Biodiversitas, 18(4), 1546-1555. https://doi.org/10.13057/biodiv/d180432.

Kurniawati N., Sari Q.W., Setiawan R.Y., Siswanto E., Fauziyah, Setiabudidaya D. and Iskandar I. (2021). Surface chlorophylla variations along the southern coast of Java during two contrasting Indian Ocean Dipole events: 2015 and 2016. Journal of Sustainability Science and Management, 16(3), 116-127.

Levine A.F.Z. and McPhaden M.J. (2016). How the July 2014 easterly wind burst gave the 2015-2016 El Niño a head start, Geophysical Research Letters, 43, 6503-6510. https://doi. org/10.1002/2016GL069204.

L'Heureux M.L., Takahashi K., Watkins A.B., Barnston A.G., Becker E.J. and Di Liberto T.E. (2016). Observing and predicting the 2015-16 El Niño, Bulletin of the American Meteorological Society, 98(7), 1363-1382. https://doi. org/10.1175/BAMS-D-16-0009.1. 
Lu B. and Ren, H-L. (2020). what caused the extreme indian ocean dipole event in 2019? Geophysical Research Letters, 47(11). https://doi.org/10.1029/2020GL087768.

Muskananfola M.R. and Jumsar W.A, (2021). Spatio-temporal distribution of chlorophyll-a concentration, sea surface temperature and wind speed using aqua-modis satellite imagery over the Savu Sea, Indonesia. Remote Sensing Applications: Society and Environment, 22, 1-9. https://doi.org/10.1016/j.rsase.2021.100483.

Palmeiro F.M., Iza M., Barriopedro D., Calvo N. and GarcíaHerrera R. (2017). The complex behavior of El Niño winter 2015-2016. Geophysical Research Letters, 44, 2902-2910.

Satria F., Setyadji B. and Utama A. (2012). Species composition and distribution of deep-sea fishes of Sangihe and Talaud, North Sulawesi waters (in Indonesian). BAWAL, 4(3), 149159.

Setiawan R.Y., Setyobudi E., Wirasatriya A., Muttaqin A.S. and Maslukah L. (2019). The influence of seasonal and interannual variability on surface Chlorophyll-a off the Western Lesser Sunda islands. IEEE Journal of Selected Topics in Applied Earth Observations and Remote Sensing (JSTARS), 12(11), 4191-4197. https://doi.org/10.1109/JSTARS.2019. 2948385.

Setiawan R.Y., Wirasatriya A., Hernawan U., Leung S. and Iskandar I. (2020). Spatio-temporal variability of surface chlorophyll-a in the Halmahera Sea and its relation to ENSO and the Indian Ocean Dipole. International Journal of Remote Sensing, 41(1), 284-299. https://doi.org/10.1080/ 01431161.2019 .1641244$.

Siswanto E., Horii T., Iskandar I., Gaol J.L., Setiawan R.Y. and Susanto R.D. (2020). Impacts of climate changes on the phytoplankton biomass of the Indonesian Maritime Continent. Journal of Marine Systems, 212, 1-15. https://doi.org/10.1016/j.jmarsys.2020.103451.

Sprintall J., Gordon A.L., Koch-Larrouy A., Lee T., Potemra J.T., Pujiana K. and Wijffels S.E., (2014). The Indonesian seas and their role in the coupled Ocean-climate system. Nature Geoscience, 7(7), 487-492. https://doi.org/10.1038/ ngeo2188.

Susanto R.D. and Marra J. (2005). Effect of the 1997/98 El Nino on Chlorophyll-a Variability along the Southern Coasts of Java and Sumatra. Oceanography, 4(18), 124-127. https://doi.org/10.5670/oceanog.2005.13.

Susanto R.D., Moore T.S. and Marra J. (2006). Ocean color variability in the Indonesian Seas during the SeaWiFS era. Gcubed, 7, 1-16. https://doi.org/10.1029/2005GC001009.

Verhoef A. and Stoffelen A. (2013). ASCAT Coastal Winds Validation Report, v1.5, May Technical Note SAF/OSI/CDOP/KNMI/TEC/RP/176, http://projects.knmi.nl/ scatterometer/publications/pdf/ASCAT_validation_coa.pdf.

Veron J., Devantier L.M., Turak E., Green A.L., Kininmonth S., Stafford-Smith M. and Peterson N. (2009). Delineating the Coral Triangle. Galaxea, Journal of the Coral Reef Studies, 11, 91-100. https://doi.org/10.3755/galaxea.11.91

Wirasatriya A., Setiawan J.D., Sugianto D.N., Rosyadi I.A., Haryadi H., Winarso G., Setiawan R.Y. and Susanto R.D. (2020b). Ekman dynamics variability along the southern coast of Java revealed by satellite data. International Journal of Remote Sensing, 41(21), 8475-8496. https://doi.org/10.1080/0143 1161.2020.1797215.

Wirasatriya A., Setiawan R.Y. and Subardjo P. (2017). The effect of ENSO on the variability of chlorophyll-a and sea surface temperature in the Maluku Sea. IEEE Journal of Selected Topics in Applied Earth Observations and Remote Sensing (JSTARS), 10(12), 5513-5518.

Wirasatriya A., Sugianto D.N., Maslukah L., Ahkam M.F., Wulandari S.Y. and Helmi M. (2020a). Carbon dioxide flux in the Java Sea estimated from satellite measurements. Remote Sensing Applications: Society and Environment, 41(21), 8475-8496. https://doi.org/10.1016/ j.rsase.2020.100376.

Wirasatriya A., Susanto R.D., Kunarso K., Jalil A.R., Ramdani F. and Puryajati A.D., 2021. Northwest monsoon upwelling within the Indonesian seas. International Journal of Remote Sensing, 42(14), 5437-5458. https://doi.org/10.1080/ 01431161.2021.1918790. 